\title{
HERALDIKA STREDOVEKÝCH SPIŠSKÝCH PREPOŠTOV, PREDOVŠETKÝM VO SVETLE SFRAGISTICKÝCH PAMIATOK (14. - 16. STOROČIE) ${ }^{1}$
}

\author{
Heraldry of the Medieval Spiš Provosts, \\ Primarily in the Light of Sphragistic Material \\ (14th - 16th Century) \\ Miroslav Glejtek
}

DOI: 10.17846/CL.2021.14.1.65-87

\begin{abstract}
GLEJTEK, Miroslav. Heraldry of the Medieval Spiš Provosts, Primarily in the Light of Sphragistic Material (14th - 16th Century). Heraldry was an important part of the culture of the medieval European society. This identifying system was originally connected primarily with the military. Later, however, the use of the coats of arms extended to the sphere of the church. In the 14th century, the coats of arms began to be actively used by high-ranking representatives of chapters. This study focuses on the coats of arms used by the medieval provosts of the Spiš collegiate chapter of St. Martin. The study of the church heraldry depends, first of all, on the amount of available sources. In the case of the Spiš provosts, the preserved items are primarily seals and also some artistic items from the architectural context. Until now, the evidence of the use of the coat of arms or the preserved heraldic elements by ten medieval provosts has been found. In most cases, these belong to the hereditary coat of arms of nobility which, by the end of the medieval period, displayed also insignia to indicate rank in a church. Although we are far from complete mapping of all coats of arms which were in use in Spiš, thanks to the preserved sources we can reconstruct their history and development rather well. Several items discussed in this paper have not been published, neither used in history research so far.
\end{abstract}

Keywords: coat of arms, heraldry, seal, provost, Spiš, the Middle Ages

\section{Úvod}

Hoci sa zrod heraldiky a používanie erbov v 12. storočí výrazne spája s vojenstvom, už v najstaršom období môžeme sledovat', ako sa dostáva aj do celkom civilných sfér života západoeurópskej spoločnosti. $Z$ erbu sa stal prvoradý prostriedok identifikácie nielen jednotlivca, ale aj celých rodov, či výsadných komunít $\mathrm{v}$ najširšom zmysle slova. $\mathrm{V}$ našom domácom prostredí sa s prvými erbmi začíname stretávat’ na prelome 12. a 13. storočia, pričom další vývoj heraldike skutočne prial. Svedčí o tom množstvo prameňov, v staršom období predovšetkým sfragistických. V cirkevnej sfére sa erby presadili o niečo neskôr. Toto zaostávanie za profánnym prostredím možno sledovat už v západnej Európe, pričom v Uhorsku je tento posun ešte výraznejší. Neskoršia

1 Štúdia je výsledkom projektu IRT (International Research Teams at Philosophical Faculty, University of Hradec Králové) s názvom Mediaeval Ecclesiastical Sigillography, riešenom v rokoch 2019 - 2021. 
recepcia heraldiky v cirkvi býva spájaná so značnou nedôverou voči tejto „novinke“ spočiatku spájanej s vojenstvom a osobitne rytierskymi hrami. Heraldiku nemala cirkev pod kontrolou a mohla ju ovplyvňovat' len minimálne (Pastoureau 2018, 197). Po počiatočnom váhaní sa však cirkev s heraldikou naplno zžila. Svedčí o tom výzdoba v katedrálach a kostoloch vo forme nástenných malieb, náhrobkov, vitráží, neskôr mortuárií, nehovoriac o liturgických predmetoch, ako sú kalichy, bohoslužobné knihy, ornáty, berly, mitry atd. Všade tam nachádzali erby svoje miesto hlboko do novoveku. Najstaršie zachované pramene domáceho pôvodu pochádzajú z 1 . tretiny 14. storočia. Medzi prvými začali erby aktívne používat arcibiskupi a biskupi, ku ktorým sa vzápätí pridali prepošti a kanonici kapitúl, či opáti kláštorov. V odbornej spisbe je zmapovaná predovšetkým heraldika najvyšších predstavitelov (arci)diecéz. Ovela skromnejšie sú publikované poznatky k erbom kapitulného duchovenstva. Súvisí to s torzovitostou zachovaných prameňov, ktorých množstvo stúpa až v 15. storočí. Vzhladom na súčasný stav poznania som sa rozhodol pre zmapovanie heraldiky stredovekých spišských prepoštov. Viedla ma k tomu predovšetkým súčasná solídna znalosṫ zachovaných prameňov, najmä pečatí. Tento príspevok nadväzuje na prácu o prepoštských pečatiach, ktorá vyšla nedávno. Možno z nej získat aj dalšie informácie o prameňoch, ktoré som využil aj pre potreby tejto štúdie (Glejtek 2018, 55-71). V predloženom príspevku som venoval pozornost' len tým osobnostiam, pri ktorých existujú indície o tom, že erb skutočne vlastnili a používali. V niektorých prípadoch som pre potreby rekonštrukcie erbov využil aj heraldické pamiatky, ktoré vznikli v čase pôsobenia prelátov na iných cirkevných postoch. Pri absencii takýchto prameňov som sa pokúsil podobu erbu načrtnút aspoň na základe podoby rodového šlachtického erbu, ktorý používali prepoštovi príbuzní. V heraldike vždy platilo, že neexistuje erb bez farieb (Pastoureau 2018, 200), v tejto práci je však opomenuté všetko, čo súvisí s farebnostou erbov, hoci každý erb nepochybne mal svoje tinktúry. Dôvodom je fakt, že charakter prameňov, ktoré máme $\mathrm{k}$ dispozícii nám dáva len vel'mi obmedzené možnosti výskumu farebnosti týchto erbov. Vo viacerých prípadoch existujú farebné varianty, ktoré však pochádzajú z mladšieho obdobia a navyše sú často variabilné. Prisudzovaním tinktúr štítom a figúram spät do minulosti by sme sa dostali na velmi neistú pôdu s hrozbou anachronického prístupu. Jedinou výnimkou v našom prípade je farebný erb arcibiskupa Juraja z Pavloviec, ktorý sa zachoval ako súčast' výzdoby jeho osobného breviára.

\section{Erby prepoštov}

Prvým prepoštom, pri ktorom máme zmienky o používaní vlastného erbu, bol člen jednej z vetiev významného spišského rodu pánov z Lomnice, Mikuláš z Huncoviec (1349 - 1356). V staršej literatúre sa spomína prepoštov náhrobok, ktorý mal byt’ umiestnený v kostole v Huncovciach. Ten sa ale, žial', dodnes nezachoval. Miesto posledného odpočinku isto súviselo s držbou patronátneho práva prepošta nad kostolom (Labanc 2011, 136-138). Pre nás je zaujímavá zmienka o tom, že súčastou výzdoby náhrobku mal byt aj prepoštov erb. Ten pravdepodobne korešpondoval s erbovým znamením, ktoré používali aj príslušníci iných vetiev rodu, napr. páni z Brezovice. Je ním nevšedné znamenie kamzíka (Berzeviczy 1903, 97). O celkovej podobe erbu, žial', nevieme povedat’ viac. Otázne je, či išlo len o figúru zvierata, alebo či bolo vložené do štítu a či boli súčastou erbu aj nejaké mimoštítové, externé súčasti. Rovnako nepoznáme detaily erbového znamenia. V literatúre sa často spomína, že kamzík vyskakuje zo stredného víšku trojvršia. Na najstarších zachovaných pamiatkach bol erb zobrazený variabilne. Napríklad na pečati taverníka Petra z Brezovice je trojvršie jasne viditelné (1421, MNL OL DL 74887). Na jeho náhrobnej doske z roku 1433 však absentuje (obr. 1; Csergheö - Csoma 1890, 33-35; Čovan 2015, 110-111, 128). Na náhrobku iného člena tohto rodu, ale z rovnakého obdobia, nitrianskeho biskupa Juraja, je trojvršie súčastou erbu 
(obr. 2; 1437, Medvecký 2011, 224). Rodový erb neskôr prešiel vývojom a bol dopĺňaný aj o dalšie figúry (Novák 1986, 24-25).

Aktívne používal svoj erb prepošt Dominik (1357 - 1360). Nachádza sa na jeho vel'kej pečati a má zaujímavé formálne stvárnenie (1357, SA Le, f. SaSk, Scr. IX, Fasc. 5). V dolnej časti pečate sú dva ranogotické, dolu zašpicatené štíty s rozdielnym obsahom (obr. 3). Aby sme mohli porozumiet’ obsahu týchto štítov, je potrebné osvetlit základnú podobu šlachtických erbov. Tie začali vznikat v priebehu 12. storočia, pričom vel’mi skoro imitovali rytiersku zbroj. Základom erbu bol štít, na ktorom spočívala zatvorená prilba. Z nej po stranách splývali prikrývadlá pripomínajúce farebné kusy látky. Tie sa v hornej časti spájali do točenice, respektíve boli prekryté malou korunkou. Napokon bol na prilbe umiestnený plastický klenot. Ten mal vo vrcholnom stredoveku značné rozmery a v prostredí rytierskej kultúry sa tešil vel'kej oblube. Obzvlášt' efektne pôsobili plastické klenoty na slávnostnej zbroji. Rytieri klenoty používali na prilbách predovšetkým počas turnajových hier (Vrtel 2003, 85-87; Glejtek 2013, 39-55). Na druhej strane praktické používanie klenotu netreba preceňovat'. Napriek obrovskej popularite, viac než v praktickom používaní, našiel uplatnenie v obrazovej (ikonografickej) rovine (Pastoureau 2018, 210). Neraz dokonca zastupoval štít. V 14. storočí, ked' sa v Uhorsku začíname stretávat’ s erbmi aj u cirkevných hodnostárov, môžeme takýto kompletný erb, resp. klenot s prilbou vidiet̉ len zriedkavo. ${ }^{2}$ Väčšina prelátov sa uspokojila s erbovým štítom bez vedlajších súčastí. V dolnom rohu vel'kých pečatí boli najčastejšie stvárnené dva malé štítky s identickým znamením, sprevádzajúce po stranách postavu majitela pečate (Glejtek 2017, 16-17; Végh 1935, 1-4). Prepošt Dominik bol členom rodu Bubekovcov. Neprekvapuje teda, že aj ako cirkevný hodnostár používal rodovú symboliku (Siebmacher Csergheö1885-1892, heslo: Bebek v. Pelsöcz; Csoma 1888, 159-164). Na Dominikovej pečati však obsah štítov nie je rovnaký. V lavom štíte je umiestnené bubekovské znamenie v podobe dvojramenného kríža. Vzhladom na maličké rozmery štítu nebolo možné vyryt do pečatidla d’alšie detaily štítového znamenia. Na rodovom erbe $z$ hornej časti kríža vyrastá na obidve strany trojica pier (obr. 4). Tie v štíte nemožno identifikovat’ a je pravdepodobné, že vzhladom na rozmery štítu ani neboli jeho súčastou. V pravom štíte je nepochybne stvárnený klenot rodového erbu (Vrtel 2003, 88-89). Ten má podobu korunovanej panny, ktorá v ústach drží dvojicu dohora prehnutých rýb. Dominikov erb je tak prejavom heraldickej kreativity, ktorá je medzi prelátmi tohto obdobia skôr výnimočná.

Aj erb dalšieho prepošta Benedikta (1360 - 1379) je zobrazený na velkej pečati (1363, Vrtel 2003, 102). Má podobu ranogotického štítu, ktorý je umiestnený v strede dolného rohu pečate (obr. 5). V tomto prípade už nesprevádza postavu klačiaceho prepošta, ale ho priamo zastupuje. Ukazuje to na fakt, že erb sa čoraz viac stával zástupným symbolom, ktorý bez problémov suploval aj portrét preláta. Štít vypĺn̆a jeleň, ktorý je otočený heraldicky doprava. ${ }^{3}$ Benedikt pochádzal z rodu Himházi, ktorý mal podla Pála Engela a Pála Lőveia genealogické väzby na rod Himfi (Engel - Lővei 2015, 123). Jedným z dôkazov tohto spojenia je práve erbové znamenie. Pri štúdiu Benediktovej heraldiky je pre nás dôležitá aj pečat', ktorú používal po odchode zo Spiša, v hodnosti vesprímskeho biskupa (1387, MNL OL DL 69994). V nej dva ranogotické štíty nesú identické znamenie jeleňa. Jeleň v lavom štíte hladí heraldicky dolava a ten v pravom štíte doprava (obr. 6). Nejde pritom o chybu. Pravidlo heraldickej galantnosti hovorí o tom, že figúry zvierat by mali

2 Možno tu spomenút napríklad rábskeho biskupa Kolomana (1373), ktorý ako nelegitímny královský syn používal upravený anjouovský erb aj so všetkými súčastami šlachtického erbu. Iba prilbu s klenotom, bez štítu, na dvoch typoch velkých pečatí zobrazil jágerský biskup Michal zo Sečian (1367) (Glejtek 2020, 24-25).

3 V heraldike sa erby popisujú zrkadlovo obrátene, čiže z pozície toho, kto erb niesol pred sebou. Z pohladu pozorovatela je heraldicky pravá čast̉ vlavo a naopak. 
pozerat' k sebe a nie jedným smerom. Či už ide o figúry v jednom štíte, alebo aj v kompozícii viacerých štítov (Galbreath - Jéquier 1978, 87-89). To Benediktova heraldická symbolika plne rešpektuje. Porovnanie erbov v obidvoch pečatiach hovorí o tom, že prepošt stabilne používal rodový erb a dôsledne tak dodržiaval aj dalšie pravidlo o nemennosti erbového znamenia.

Na velkých kombinovaných pečatiach bol erb len vel’mi malým a tažko čitatelným doplnkom. Pre potreby heraldického bádania sú často využitelnejšie iné druhy pečatí. Napríklad pečatný prsteň mal síce ovela menšie rozmery, ale vd’aka tomu, že na ňom býva zobrazený len erb, je väčší a čitatel’nejší aj v detailoch. Takéto malé pečatidlo vlastnil prepošt Juraj z Čorne (1393 - 1405/1406) (1402, MNL OL DL 60492). Stretávame sa tu s jedinečným a nezamenitelným rodovým znamením v podobe orlieho krídla s pazúrmi (obr. 7). Ide o známy heraldický symbol významného uhorského rodu Kanižaiovcov. V rôznych variantoch erbu býva doplnený ešte o nebeské figúry - hviezdu a mesiac (obr. 8; Siebmacher - Csergheö 1885-1892, heslo: Kanisay, I.). Táto figúra nie je v prepoštovej erbovej pečati zasadená do štítu, ale volne sa vznáša v pečatnom poli. Je to vlastne najjednoduchší spôsob zobrazenia erbovej symboliky. Striktne vzaté, nemožno hovorit’ o erbe v pravom zmysle slova, kedže sa figúra nenachádza v štíte. Mnoho prameňov z tohto obdobia nás ale presviedča o tom, že prílišné lipnutie na forme nevedie k žiadnemu výsledku. Doboví rytci, maliari či kamenári pracovali s erbovou symbolikou volne. Či už ide o zobrazenie štítu, „čisto“ figúry, alebo prilby s klenotom bez štítu, bez akýchkolvek pochybností ide stále o heraldiku.

Malú erbovú pečat používal aj Juraj z Pavloviec (1408 - 1419). Vzhladom na to, že bola k dokumentu pritlačená cez clonu a je zle čitatelná, nemožno ju použit na presnú identifikáciu obsahu erbu (1418, MNL OL DF 234262). Napriek tomu sa môžeme pokúsit o rekonštrukciu prepoštovho erbu. Po odchode zo Spiša získal Juraj hodnost’ sedmohradského biskupa (1419 - 1423) a neskôr ostrihomského arcibiskupa (1423 - 1439). Z tohto obdobia pochádzajú dva typy jeho erbových pečatí. V prvom prípade je znamenie menej zretel'né. Nepochybne sa tu ale nachádza $\mathrm{z}$ dvoch tretín zobrazená postava dlhovlasého muža, ktorý drží v rukách tažko identifikovatelný predmet, pripomínajúci skôr šablu (1428, MNL OL DL 61418). Čitatelnejšia je mladšia pečat' (1437, AMB, f. MMB, sign. 1490; 1438, Hegedüs 2000, 119, Nr. 90). V pečatnom poli je figúra dlhovlasého muža vyrastajúceho z koruny, ktorý v lavici drží knihu ozdobenú sponou, pričom si pravou rukou si chytá dlhú bradu (obr. 9-10). O korektnosti popisu tejto figúry nás presviedča aj iný dôležitý prameň. Juraj nechal do vlastného iluminovaného breviára, ktorý vznikol okolo roku 1435, namalovat aj vlastný erb s rovnakým znamením. Modrý štít je v tomto prípade ešte prevýšený biskupskou mitrou (Universitätsbibliothek Salzburg, Sign.M. II. 11). Je to typické erbové znamenie, s ktorým sa stretávame aj u dalších členov rodu pánov z Pavloviec (obr. 11; Siebmacher - Csergheö1885-1892, heslo: Pálóczy, I. v. Pálócz). Ak vychádzame z premisy, že prelát používal rodové znamenie dlhodobo nezmenené, dá sa predpokladat', že ho vlastnil aj ako spišský prepošt.

Erb sa nachádza aj v dolnom rohu velkej pečate prepošta Juraja z Kežmarku (1419 - 1433). Má podobu malého neskorogotického, poloblého štítu (1421, MNL OL DL 74887). Jeho obsah je však na pečati len vel’mi tažko čitatelný (obr. 12). Len vel’mi hypoteticky možno predpokladat', že by mohlo íst' o erb pánov z Lomnice, resp. niektorej z ich vetiev (Labanc - Glejtek 2015, 34). V takom prípade sa črtá možnost', že hlavným erbovým znamením by mohol byt kamzík, ako to bolo v prípade prepošta Mikuláša. Doposial známa genealógia Juraja a jeho predkov nám zatial' neumožňuje túto záležitost' lepšie objasnit'. V súvislosti s erbom prepošta je potrebné spomenút ešte jeden prameň. Je ním malá okrúhla pečat pritlačená k Jurajovej listine z roku 1432 (obr. 13; MNL OL DL 12448). Kedže je umiestnená pod clonou a má malé rozmery, je rozlíšenie symbolov náročné. Nazdávam sa, že by na pečati mohol byṫ zobrazený naklonený štít, na ktorom je položená turnajová prilba, čo by erb približovalo šlachtickej heraldike. Ide zatial' len o hypotézu, ktorú bez kvalitnejšie zachovanej pečate nemožno potvrdit'. 
Majitelom minimálne dvoch čisto erbových pečatidiel bol prepošt Ján Stock (1433 - 1464). Je možné, že mohlo íst' dokonca o prvého spišského prepošta, ktorý sa úplne vzdal používania velkého pečatidla s kombinovanými motívmi a pečatil iba erbovými pečatidlami menších rozmerov (1449, Vrtel 2003, 127; 1450, ASB, f. RaSk, Scr. 2, Fasc. 2, Nr. 15). V takom prípade ide nepochybne o ústup od náboženskej pečatnej symboliky a proces profanizácie pečatí cirkevných hodnostárov (Rábik 2003, 332). Na zachovaných pečatiach sa nachádza neskorogotický poloblý štít. Erbovým znamením sú skrížené konáriky vyrastajúce z jedného koreňa (obr. 14-15). Zaujímavé je hladat pôvod tohto erbového znamenia. Prepošt bol panovníkom nobilitovaný v roku 1431 a v tom čase zrejme prijal aj erb. Nie je síce jasné ako erb vznikol, ale nazdávam sa, že vodidlom k výberu figúr je prepoštovo prímeno. Slovo stock možno zo stredovekej nemčiny preložit ako palica, kôl či kmeň (Lexer 1986, 212) V erbe je podobné znamenie nepochybne stvárnené. Nešlo by pritom o nič neobvyklé, pretože v stredoveku boli velmi oblúbené tzv. hovoriace erby. Erbová figúra v nich priamo odkazovala na meno majitela (Hauptmann 1914, 28). Dodnes ich považujeme za najhodnotnejšie a najkrajšie ukážky stredovekej heraldiky.

Jediným stredovekým prepoštom, po ktorom sa nám zachovala autentická podoba erbu priamo na architektúre prepoštského chrámu v Spišskej Kapitule, bol Gašpar Back (1464 - 1494). Erb je súčastou klenbového svorníka, ktorý vznikol počas dostavby v roku 1491. Tvorí ho neskorogotický štít vyplnený otvorenou korunou, z ktorej vyrastá vták s rozpätými krídlami. Na štíte spočíva mitra (obr. 16; Janovská - Olejník 2017, 211). Len nedávno sa podarilo objavit dva typy prepoštových pečatí, na ktorých je tiež zobrazený erb. V oboch prípadoch je neskorogotický štít vyplnený rovnakými figúrami - z koruny vyrastajúcim vtákom. Na jednom type pečate sú však badatelné ešte dve dalšie menšie figúry. Nachádzajú sa nad vtáćími krídlami po stranách a zdá sa, že by mohlo íst’ o maličké maltské krížiky, resp. štvorlupeňové kvety (ruže?) (obr. 17-18, 1488, ŠA Pr-AP, f. MMK, sign. U949/21). Otázkou je, akého operenca prepošt vo svojom erbe zobrazil. Na prvý pohlad je v prípade svorníka a spomenutého typu pečate badatelný dlhší vtáčí krk, ktorý evokuje hus, resp. labut'. Na inom, staršom type pečate, však pripomína skôr orla, resp. havrana (obr. 19; 1474, AGAD, f. ZDP, Sign. 5583). Prepoštovým erbom sa zaoberal už znalec dejín Spišského prepoštstva Karol Wagner, ktorý spomína erb na prepoštovom náhrobku. Podla jeho názoru bol v erbe zobrazený havran, alebo orol so zdvihnutými krídlami, po stranách ktorého sa mali nachádzat’ dva polmesiace (Wagner 1778, 72; Janovská - Olejník, 213). V roku 1472 získal prepošt aj jeho nástupcovia od pápeža Sixta IV. právo používat pri liturgii pontifikálne insígnie mitru a berlu. ${ }^{4}$ Toto exkluzívne právo sa prejavilo aj v prepoštovej heraldike. Na I. type pečate, ktorú poznáme z roku 1474, je erb tvorený ešte iba štítom. Mitra sa objavuje až na II. type pečate zachytenú na dokumentoch z rokov 1479 - 1489 a na spomenutom svorníku. Bola umiestnená do stredu horného okraja štítu s vejúcimi fimbriami po stranách, tak ako to poznáme z erbov súdobých biskupov. V súvislosti s pečatami je potrebné dodat, že prepošt po udelení privilégia mohol ešte nejaký čas používat staršie pečatidlo. Nové, doplnené o exkluzívny symbol určený len malej skupine vyvolených, si mohol dat vyhotovit až neskôr. V praxi sa však stretávame aj s tým, že v rovnakom čase preláti používali rôzne varianty erbu, ktorých súčastou mohli, ale nemuseli byt aj mimoštítové prvky. Celkovo erby cirkevných hodnostárov v 15. storočí smerovali k určitej stabilnej štruktúre. Štít býval v závislosti od postavenia majitela v cirkevnej hierarchii doplnený

4 Porovnaj: „Nos igiturtuis in hac parte supplicationibusinclinati, ut tu, qui, utasseris, de nobili ex utroqueparenteprocreatusexistis, et successorestuipraepositipraedictaeecclesiae, qui pro temporeerunt, pro maiorieorum honore, acreverentia, dictaequeecclesiaevenustate, et decor in praefataecclesia, et extra eam in quibuscunquelocis, in quibusipsepraepositus pro temporeexistens, iurisdictionepraedictauticonsuevit, mitra etiamauriphrygiata, seumargaritis, etlapidibuspretiosisdecorata, acbaculopastorali, etaliispontificalibusinsigniis, quotiestibi, et aliisplacuerit, libereuti [...] de specialigratia tenore presentiumindulgemus" (Wagner 1774, 347). 
o mimoštítové odznaky hodnosti. Biskupi na štít kládli mitru, neskôr i berlu, kardináli zasa klobúk a arcibiskupi procesiový kríž. Nešlo však o zásady, ktoré sa v praxi striktne dodržiavali. Dôležité bolo, aby mal klerik na tieto atribúty moci nárok, pretože bez toho ich používat' nemohol, čo zdôrazňuje už v 14. storočí aj slávny znalec dobovej heraldiky a práva Bartol Saxoferrato. ${ }^{5}$ Zároveň ale platí, že prelát, ktorý mal na tieto odznaky moci právo, nemusel ich vo svojom erbe zobrazit (Glejtek 2020, 23-29).

V slovenskej odbornej literatúre nebola doposial’ venovaná väčšia pozornost̉ ani erbu prepošta Juraja z Mecske (1494 - 1505, 1507 - 1508). Ten sa zachoval na jeho malej prsteňovej pečati. V jej pečatnom poli sa nachádza neskorogotický štít s jemne prehnutými bokmi nenápadne naznačujúci postupný príklon k renesancii. V štíte je umiestnená otvorená listová koruna, cez ktorú prechádza šíp. Na jeho hrote je položená šesthrotá hviezda a heraldicky vlavo polmesiac (obr. 20; 1498, MNL OL DL 59875).V tomto prípade ide o erb príslušníka šlachtického rodu Mekcse (Csiffáry 2005, 101-102; Siebmacher - Csergheö1894, heslo: Mekcsey).

Podla najnovších výskumov nastúpil dočasne po Jurajovi na prepoštský post titulárny oropský biskup Ján z Mecske (1504 - 1505). ${ }^{6} \mathrm{~V}$ tomto prípade máme zachovanú len jeho erbovú biskupskú pečat', ešte z r. 1503 (SA Le, f. SaSk, Nr. 5). Nachádza sa v nej neskorogotický poloblý štít s rovnakou symbolikou ako u Juraja, len s tým rozdielom, že na štíte je položená biskupská mitra (obr. 21). Potvrdzuje to, že išlo o príslušníkov rovnakého šlachtického rodu a nedá sa vylúčit ani to, že išlo o bratov. Je vel’mi pravdepodobné, že Ján rovnakú erbovú symboliku používal aj po tom, ako bol menovaný spišským prepoštom.

Erb používal aj posledný stredoveký prepošt Ján Horváth (1511 - 1544). Jeho základom je štít vyplnený rodovým znamením gryfa s predmetom v rukách. V oktogonálnej prsteňovej pečati sa dá predmet jednoznačne identifikovat ako koruna (obr. 22; 1534, SA Le, f. SpP, Cap. 16, Fasc. 1). V súvislosti s druhou, okrúhlou pečatou, sa stretneme aj s názorom, že by mohlo íst’ o ružu (obr. 23; 1537, Vrtel' 2003, 156). V súlade s názormi dalších autorov sa však prikláňam k otvorenej listovej korune (Obr. 24; Vítek - Matugová 2007, 52;Pongrácz 2019, 177; Siebmacher Csergheö1885-1892, heslo: Horváth, VI. v. Lomnicza-Kissevich). V prsteňovej pečati je erb tvorený neskorogotickým štítom s náznakmi renesančných výkrojov hornej a bočných strán. Na štíte spočíva mitra. Zaujímavý variant poskytuje druhý typ pečate. V nej je na štíte položená mitra prevýšená ešte klerickým klobúkom. Použitie mitry bolo plne v súlade pápežského privilégia z roku 1472, ktorým Gašpar Back a jeho nástupcovia získali právo nosit túto insígniu. Zvláštne v erbe pôsobí klobúk, ktorý býva v tomto období takmer výlučne symbolom kardinálskej hodnosti. U dalších klerikov sa s ním stretávame skôr výnimočne. Jedinou paralelou, s ktorou som sa v sledovanom období stretol, je miniatúra erbu v inkunábule bratislavského prepošta Juraja zo Schönbergu, kde klobúk dopÍnajú uzly na šnúrach, splývajúcich po stranách štítu. Dalo by sa to považovat za reminiscenciu na Jurajovu hodnost̉ apoštolského protonotára (Hlavačková 2015, $146,234)$.

5 Porovnaj: „[...] sú insígnie hodnosti alebo úradu, ktoré môže nosit’ každý, kto má onú hodnost’ či úrad - ako insígnie prokonzulov alebo legátov, tak ako dnes vidíme insígnie biskupov - a tie, ako hovoria zákony, môže nosit každý, kto má onú hodnost'. Iným však nie je dovolené nosit’ ich; ba dokonca kto ich nosí, dopúšta sa zločinu podvodu, a tak myslím, že ten, kto nosí insígnie doktora, hoci doktorom nie je, má byt’ potrestaný" (Saxoferrato 2009, 41, Kap. I).

6 V titulatúre listiny z 2. 7. 1505 sa uvádza jeho hodnost̉ titulárneho oropského biskupa, ako aj spišského prepošta (MNL OL DL 21449). Pôvodne privesená pečat’ na nej žial' chýba. 


\section{Záver}

Počínajúc prepoštom Pavlom na začiatku 14. storočia po Jána Horvátha v polovici 16. storočia pôsobilo podla doterajších výskumov na Spiši celkom 17 prepoštov. Vlastný erb používali prinajmenšom desiati z nich (tab. I.), hoci sa môžeme domnievat, že u niektorých d’alších sa o tom iba nezachovali dôkazy. Na základe známych dokladov môžeme konštatovat', že prienik heraldiky do spišského cirkevného prostredia korešponduje s celouhorským vývojom. Po (arci)biskupoch patrili práve prepošti k špičkám uhorského kléru. Je teda logické, že i oni mali záujem prezentovat sa aj prostredníctvom erbu. Išlo však o postupný proces, o čom svedčí aj fakt, že u prvých prepoštov 14. Storočia, Pavla, Henricha a Jána (pôsobili od 1301 - 1348), sa ich erb ešte na velkých pečatiach neobjavuje. Prepošti 15. storočia však už svoje vlastné erby stabilne na svojich pečatiach používali. Otázniky panujú len v prípade niekolkých prepoštov. Opomenút môžeme Jána de Dominis, ktorý de facto ani nenastúpil do úradu prepošta, a preto sa po ňom ani nemohli zachovat' heraldické pamiatky (Labanc - Glejtek 2015, 36). Otázna je situácia v prípade Ladislava z Čobádu, ktorý pôsobil ako prepošt na prelome 15. a 16. storočia. Poznáme jeho prsteňovú pečat', ktorú používal tak v hodnosti lektora (1505, ŠA Pr-AP, f. MMK, sign. U949/26), ako aj prepošta (1509, ŠA Pr-AP, f. MMK, sign. U949/27). Jej súčastou ale nebol erb. Stretávame sa tu s výjavom typickým pre antické gemy, resp. ich napodobeniny. Pečatnou figúrou je portrét tváre zobrazený z profilu. Na Spiši je takýto námet síce neobvyklý, ale v kontexte uhorských prameňov z tohto obdobia nie úplne výnimočný. Patrilo k „móde“, že si niektorí významnejší farári, prepošti, alebo biskupi zaobstarali pečatné prstene evokujúce návrat k antickým tradíciám populárnym v humanistickom prostredí. Takúto podobu malo nakoniec už jedno z pečatidiel, ktoré používal panovník Matej Korvín (1489, SNA, f. SaBk, Cap. E, Fasc. 14, Nr. 327). Ostáva otázkou, či prepošt Ladislav nejaký erb mal a či ho používal napríklad na inom, zatial neznámom pečatidle.

Erbové znamenia spišských prepoštov môžeme rozdelit do dvoch skupín. V prípadoch, kde poznáme bližšie genealogické väzby, vieme dokázat', že prepošti používali znamenia z rodových šlachtických erbov. U prepoštov, ktorých pôvod nepoznáme, nevieme presnejšie určit', odkial pochádzajú. Môžeme sa len domnievat', že v prípade, ak nepatrili medzi nobilitu, volili si ich sami tak, ako to poznáme aj z prostredia kanonikov a nižšie postavených klerikov neskorého stredoveku (Glejtek 2017, 19-22).

Z formálneho hladiska erby spišských prepoštov zapadajú do kontextu celouhorského vývoja. Základ vždy tvoril štít s jednou, alebo viacerými figúrami. Pristavit sa môžeme pri obohatení erbu o pontifikálne insígnie, ktorých používanie bolo viazané na pápežské privilégium. Platilo to tak pre liturgické slávenia, ako aj pre vlastnú heraldickú prezentáciu. Táto nová heraldická etapa na Spiši začína prepoštom Gašparom Backom po roku 1472. V Spišskej Kapitule mali právo používat pontifikálie automaticky všetci další prepošti. Neznamená to však, že ho vo svojej heraldike aj všetci využívali. Napríklad Juraj Mekcse mitru na erb nepoložil, ale jeho nástupca Ján Horváth už áno. Zaujímavé je porovnat' situáciu v Bratislavskej kolegiálnej kapitule. V roku 1466 získal právo používat pontifikálie jej prepošt Juraj zo Schönbergu (Hlavačková 2015, 109). Toto privilégium sa však týkalo výlučne jeho osoby, a preto si ho nechal znovu u pápeža potvrdit jeho nástupca Anton zo Šankoviec v roku 1490 (SNA, f. SaBk, Cap. A, Fasc. 1, Nr. 2). ${ }^{7}$ Mitru, ako súčast’ erbu určite používal jeho nástupca Mikuláš zo Šankoviec (1508, SNA, f. SaBk, Cap. A, Fasc. 9, Nr. 7). V erbe prepošta Hieronyma Balba ale chýba (1516, MNL OL DL 47138). Túto nestabilitu nemožno nijako preceňovat', pretože hovoríme o období, kde sa presnejšie heraldické pravidla ešte stále formovali. Napokon aj v neskoršom období platilo, že v používaní mimoštítových symbolov

Za ochotnú pomoc a konzultácie k tejto problematike dakujem PhDr. Miriam Hlavačkovej, PhD., z Historického ústavu SAV. 
moci prelátov existovala na erboch variabilita. Nešlo pritom len o otázky právneho nároku, ale aj technického prevedenia a umeleckého prejavu tvorcu daného heraldického artefaktu. Len doplním, že druhá pontifikália - berla - sa v prepoštskej heraldike nevyskytuje vôbec. Rovnako však absentuje aj v erboch biskupov, ktorí mali na tento odznak moci právo automaticky. Jej používanie sa v uhorskej biskupskej heraldike začalo naplno uplatňovat až v priebehu 16. storočia.

Odchodom Jána Horvátha z postu prepošta v roku 1544 nastúpila na Spiši nová, v mnohom odlišná, heraldická etapa. Hodnosť prepošta zastávali spočiatku biskupi diecéz obsadených Osmanmi, neskôr titulárni, resp. vyvolení biskupi (episcopi electi) (Labanc - Glejtek 2015, 57-59). Tu už je potrebné skôr než o erboch prepoštov hovorit’ o biskupských erboch v najrôznejších variáciách (Glejtek 2010, 255-266).

\section{REFERENCES}

\section{Primary sources}

Archiwum Główne Akt Dawnych w Warszawie (dalej AGAD), f. Zbiór dokumentów pergaminowych, signatúra (dalej Sign.) 5583.

Archív mesta Bratislava (dalej AMB), Fond (d’alej f.) Magistrát mesta Bratislava (dalej MMB), Signatúra (d’alej Sign.) 1490.

Archív Spišského biskupstva (dalej ASB), Fond (dalej f.) Regnikolárny archív Spišskej kapituly (d’alej RaSk), Scrinium (d’alej Scr.) 2, Fascikel (dalej Fasc.) 2, číslo (d’alej Nr.) 15.

MagyarNemzetiLevéltár, OrszágosLevéltáraBudapest, DiplomatikaiFénypgyüjtemény (dalej MNL OL DF) 234262.

MagyarNemzetiLevéltár, OrszágosLevéltáraBudapest, DiplomatikaiLevéltár (d’alej MNL OL DL) $12448,21449,47138,59875,60492,61418,69994,74887$.

Spišský archív v Levoči (d’alej SA Le), Fond (dalej f.) Súkromný archív Spišskej Kapituly (dalej SaSK), Scrinium (dalej Scr.) IX, Fascikel (dalej Fasc.) 5; Nr. 5.

Spišský archív v Levoči (d’alej SA Le), Fond (dalej f.) Spišské prepoštstvo (dalej SpP), Capsa (dalej Cap.) 16, Fascikel (dalej Fasc.) 1.

Slovenský národný archív (dalej SNA), Fond (dalej f.) Súkromný archív Bratislavskej kapituly (dalej SaBk), Capsa (dalej Cap.) A, fascikel (dalej Fasc.) 1, číslo (Nr.) 2; Cap. A, Fasc. 9, Nr. 7; Cap. E, Fasc. 14, Nr. 327.

Štátny archív v Prešove - Archív Poprad (dalej ŠA Pr-AP), Fond (dalej f.) Magistrát mesta Kežmarok (dalej MMK), Signatúra (dalej Sign.) U949/21, 26, 27.

\section{Secondary sources}

Berzeviczy, Egyed. 1903. A Berzeviczycsaládczimere. In Turul 21/3, 97-106.

Csergheö, Géza - Csoma, Josef. 1890. Alte GrabdenkmälerausUngarn. Budapest.

Csiffáry, Gergely. 2005. Mekcsey István egri várkapitány életrajzához. In Agria XLI, Eger, 99-131.

Csoma, József. 1888. Magyar sirkövek. In Turul 6/ 4, 159-164.

Čovan, Miroslav. 2015. Epigrafické a sepulkrálne pamiatky pánov z Brezovice v stredoveku a ranom novoveku. In Roháček, Jiří (eds.). Epigraphica et sepulcralia VI. Praha, 105-138.

Engel, Pál - Lövei, Pál. 2015. A magyar királyi és az osztrák hercegi család 1380. évi házassági szerződésének két sokpecsétes oklevele. In ArsHungarica 41/2, 117-133.

Galbreath, Donald L. - Jéquier, Léon. 1978. Lehrbuch der Heraldik. München. 
Glejtek, Miroslav. 2020. Heraldika v prostredí stredovekých uhorských arcibiskupov a biskupov. In Studia Historic aNitriensia, 24/1, 18-35.

Glejtek, Miroslav. 2018. Iconographic Changes of Ecclesiastic Seals in the Medieval Hungarian Kingdom (Illustrated by theExample of Spiš Chapter Provosts). In Zograf 42, 55-71.

Glejtek, Miroslav. 2017. Niekol'ko poznámok k vztahu medzi cirkevnou heraldikou a sfragistikou. In Genealogicko-heraldický hlas, 27/1-2, 15-26.

Glejtek, Miroslav. 2013. Heraldika. Úvod do štúdia erbov. Čadca.

Glejtek, Miroslav. 2010. Pečate spišských prepoštov od polovice 15. storočia do roku 1776. In Hromják, Luboslav (ed.). StudiatheologicaScepusiensia III. Z dejín Spišského prepoštstva. Spišské Podhradie, 251-271 + obr. príloha XXVII - XXXVIII.

Hauptmann, Felix. 1914. Wappenkunde. München - Berlin.

Hegedüs, András (ed.). 2000.Megpecsételttörténelem. KözépkoripecsétekEsztergomból. Esztergom.

Hlavačková, Miriam. 2015. Juraj zo Schönbergu. Bratislavský prepošt v službách cisára a krála. Bratislava.

Janovská, Magdaléna - Olejník, Vladimír. 2017. Hviezdicová klenba severnej lode. In Janovská, Magdaléna - Olejník, Vladimír (eds.). Katedrála sv. martina v Spišskej Kapitule. Spišské Podhradie, 211-213.

Labanc, Peter - Glejtek, Miroslav. 2015. Spišské prepoštstvo na prelome stredoveku a novoveku I. Príspevok k náboženským dejinám Spiša. Trnava.

Labanc, Peter. 2011. Spišskí prepošti do roku 1405. Trnava.

Medvecký, Jozef. 2011. Umelecké pamiatky a baroková výzdoba katedrálneho chrámu. In Judák, Viliam - Bednár, Peter - Medvecký, Jozef (eds.). Kolíska krestanstva na Slovensku. Nitriansky hrad a Katedrála sv. Emeráma v premenách času. Nitra.

Lexer, Matthias. 1986. MittelhochdeutschesTaschenwörterbuch. Liepzig.

Novák, Jozef. 1986. Rodové erby na Slovensku II. Petkova zbierka pečatí. Martin.

Pastoureau, Michel. 2018. Dějiny symbolů v kultuře středověkého západu. Praha.

Pongrácz, Denis. 2019. Seriesnobilium. Heraldicko-genealogický lexikón. Atlas osobných pečatí I. Bratislava.

Rábik, Vladimír. 2003. Stredoveké cirkevné pečate spišskej proveniencie. Sonda do problematiky. In Gładkiewicz, Ryszard - Homza, Martin (eds.). Terra Scepusiensis. Stav bádania o dejinách Spiša. Levoča - Wroclaw, 325-337.

Saxoferrato, Bartolus de. 2009. Tractatus de insigniis et armis. Traktát o Znameniach a erboch. Vrtel, Ladislav (ed.) - Munková, Mária (trans.). Bratislava.

Siebmacher, Johann - Csergheö, Géza. 1894. Wappenbuch des Adels von UngarnsammtdenNebenländern der St. StephansKrone. Supplementband. Nürnberg.

Siebmacher, Johann - Csergheö, Géza. 1885-1892. Wappenbuch des Adels von Ungarnsammtden

Nebenländern der St. Stephans Krone. Nürnberg.

Végh, Gyula. 1935. Jegyzetek a magyar országi püspökök címerei hez. In Turul 49/1-2, 1-4.

Vítek, Peter - Matugová, Soňa. 2007. Lexikón erbov šlachty na Slovensku III. Oravská stolica. Bratislava.

Vrtel, Ladislav. 2003. Osem storočí slovenskej heraldiky. Martin.

Wagner, Carolus. 1778. Analecta Scepusiisacri et profani. Pars III. Posonii - Viennae

Wagner, Carolus. 1774. Analecta Scepusiisacri et profani. Pars I. Viennae 
doc. PhDr. Ing. Miroslav Glejtek, PhD.

University of Hradec Králové

Philosophical Faculty

Department of Auxiliary Sciences of History and Archival Studies

Rokitanského 62

CZ-500 03 Hradec Králové

Czech Republic

mglejtek@ukf.sk

Constantine the Philosopher University in Nitra

Faculty of Arts

Department of History

Hodžova 1

94974 Nitra

Slovakia

mglejtek@ukf.sk

ORCID ID: 0000-0001-5267-593X

WOS Researcher ID: AAP-6140-2020

SCOPUS Author ID: 57191337638 
HERALDIKA STREDOVEKÝCH SPIŠSKÝCH PREPOŠTOV, PREDOVŠETKÝM VO SVETLE SFRAGISTICKÝCH PAMIATOK (14. - 16. STOROČIE)

\section{Prílohy / Appendix}

Tabulka I. Zachovanie erbov spišských prepoštov v r. 1301 - 1544

Table I. Preserved coats of arms of Spiš provosts from 1301 to 1544

\begin{tabular}{|l|l|l|l|}
\hline Meno prepošta & $\begin{array}{l}\text { Doba hodnosti } \\
\text { prepošta }\end{array}$ & $\begin{array}{l}\text { Zachovanie } \\
\text { heraldickej pamiatky }\end{array}$ & Typ prameňa \\
\hline Pavol & $1301-1315$ & NIE & \\
\hline Henrich & $1315-1322 / 1323$ & NIE & \\
\hline Ján & $1323-1348 / 1349$ & NIE & \\
\hline (Ján) & 1349 & NIE & náhrobok \\
\hline Mikuláš z Huncoviec & $1349-1356$ & NIE-zmienka & pečat' \\
\hline Dominik & $1357-1360$ & ÁNO & pečat' \\
\hline Benedikt & $1360-1379$ & ÁNO & \\
\hline Ján & $1379-1382$ & NIE & pečat' \\
\hline Mikuláš & $1382-1392$ & NIE & pečat' \\
\hline Juraj z Čorne & $1393-1405 / 1406$ & ÁNO & pečat' \\
\hline Juraj z Pavloviec & $1408-1419$ & ÁNO & pečate \\
\hline Juraj z Kežmarku & $1419-1433$ & ÁNO & \\
\hline Ján Stock & $1433-1464$ & ÁNO & architektúra, pečate \\
\hline (Ján de Dominis) & 1440 & NIE & pečat' \\
\hline Gašpar Back & $1464-1494$ & ÁNO & staršia biskupská pečat' \\
\hline Juraj z Mecske & $1494-1505$, & ÁNO & pečate \\
\hline Ján z Mecske & $1507-1508$ & NIE & \\
\hline Ladislav z Čobádu & $1504-1505$ & NIE & ÁNO \\
\hline $\begin{array}{l}\text { Ján Horváth } \\
\text { z Lomnice }\end{array}$ & $1511-1544$ & & \\
\hline
\end{tabular}




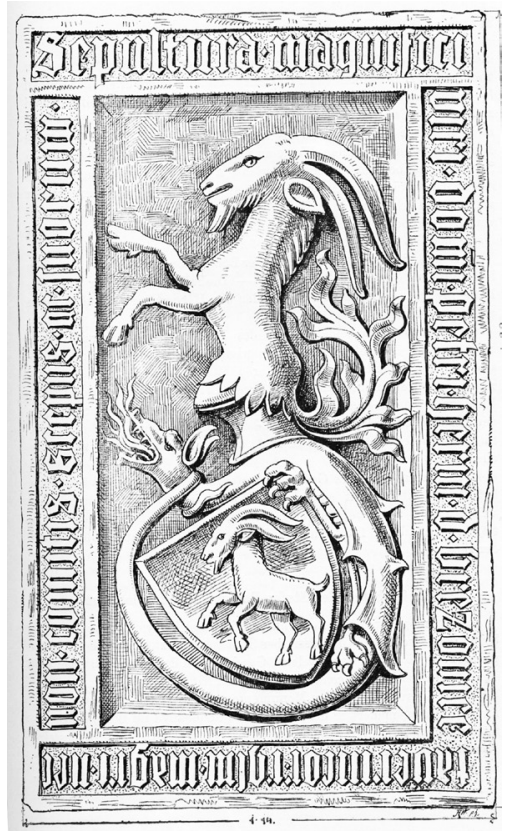

Obr. 1 Rekonštrukcia náhrobku Petra z Brezovice (zdroj: Csergheö - Csoma 1890, 35).

Fig. 1 Reconstruction of the tomb of Peter of Brezovica (source: Csergheö - Csoma 1890, 35).

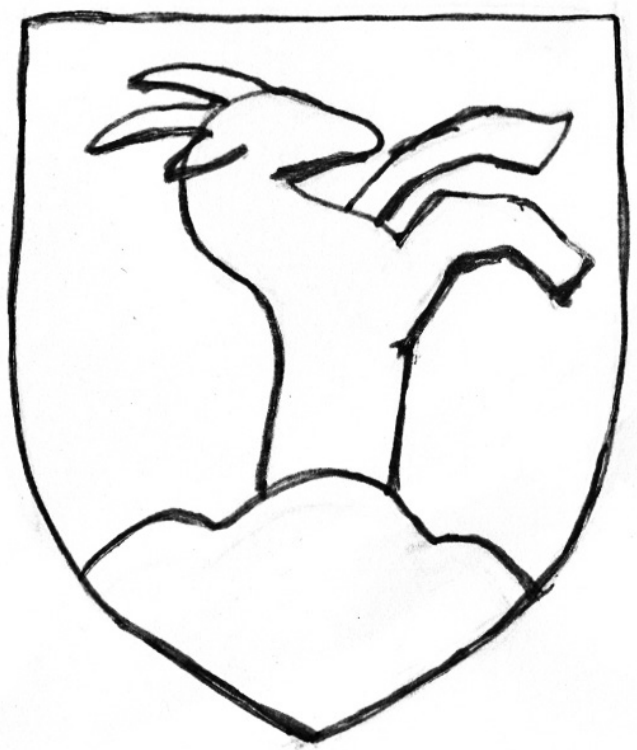

Obr. 2 Rekonštrukcia erbu na náhrobku nitrianskeho biskupa Juraja z Brezovice (podla: Medvecký 2011, 224; rekonštrukcia: M. Glejteková).

Fig. 2 Reconstruction of the coat of arms on the tomb of the Nitra bishop George of Brezovica (after Medvecký 2011, 224; drawing: M. Glejteková). 


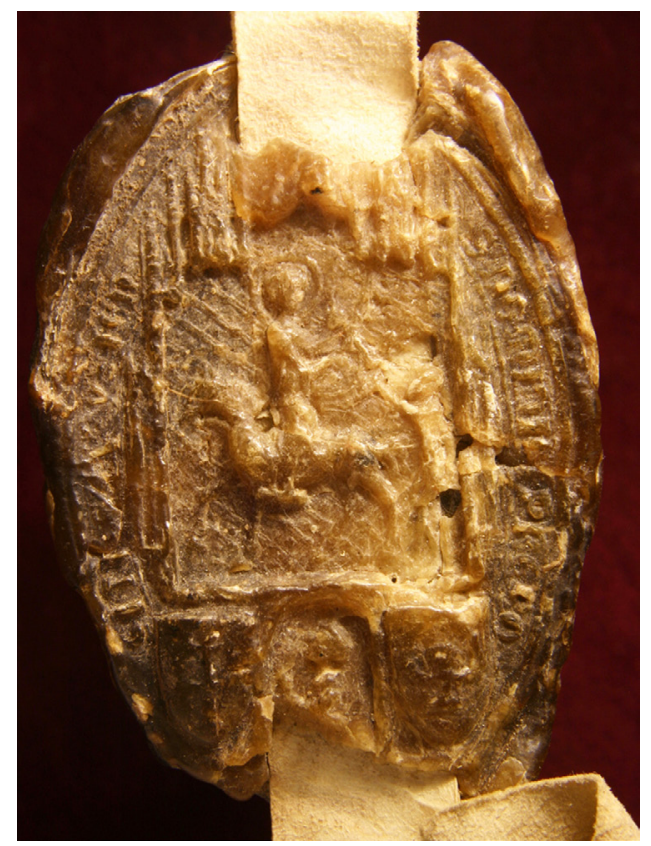

Obr. 3 Pečat prepošta Dominika z r. 1357 (zdroj: SA Le, f. SaSk, Scr. IX, Fasc. 5; foto: Š. Péchy).

Fig. 3 The seal of provost Dominic from 1357 (source: SA Le, f. SaSk, Scr. IX, Fasc. 5; photo: Š. Péchy).

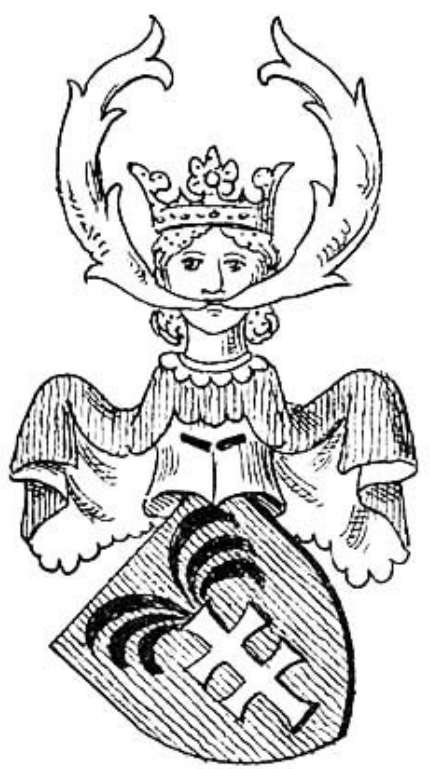

Obr. 4 Rekonštrukcia rodového erbu Bubekovcov (zdroj: Siebmacher - Csergheö 1885 - 1892).

Fig. 4 Reconstruction of the coat of arms of the Bubek family (source: Siebmacher - Csergheö 1885 - 1892). 


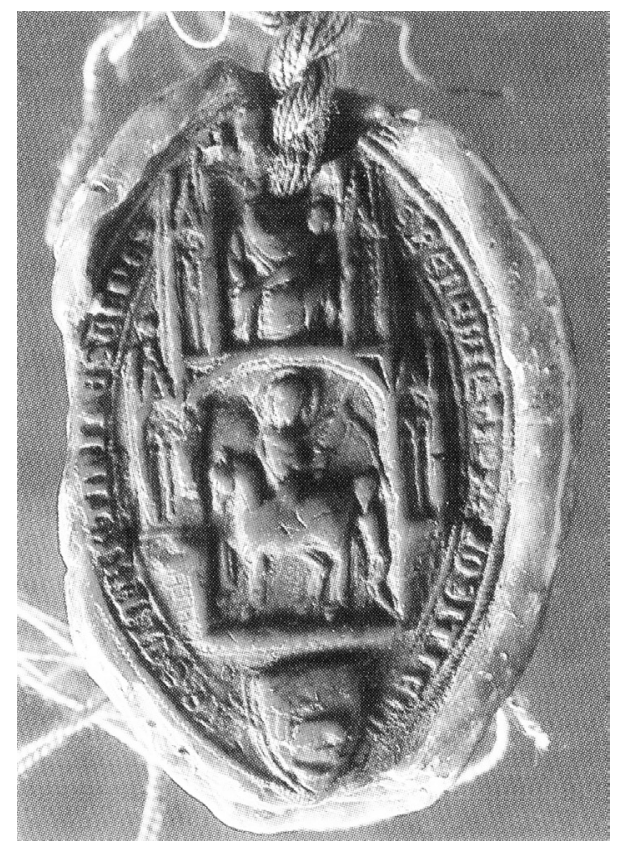

Obr. 5 Pečat' prepošta Benedikta z r. 1363 (zdroj: Vrtel' 2003, 89).

Fig. 5 The seal of provost Benedict from 1363 (source: Vrtel' 2003, 89).

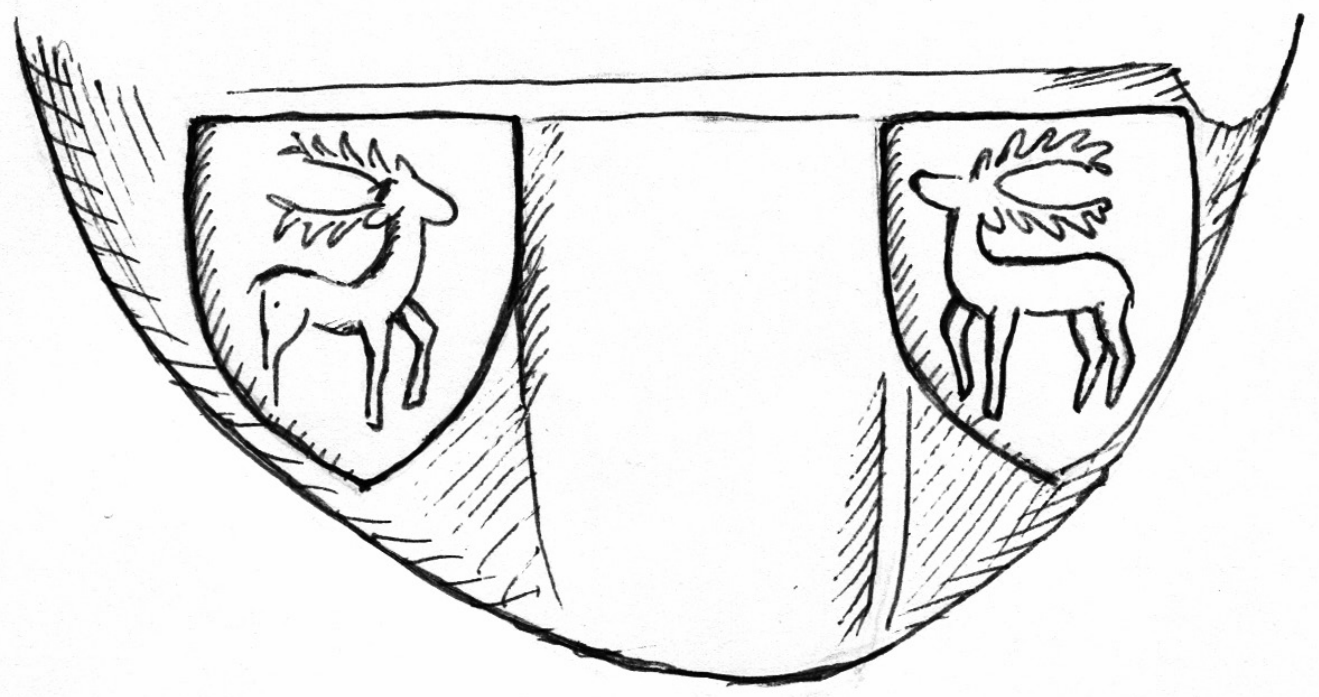

Obr. 6 Rekonštrukcia erbových štítov na pečati vesprímskeho biskupa Benedikta z r. 1387 (podla: MNL OL DL 69994; rekonštrukcia: M. Glejteková).

Fig. 6 Reconstruction of the shields on the seal of the Veszprem bishop Benedict from 1387 (after MNL OL DL 69994; drawing: M. Glejteková). 


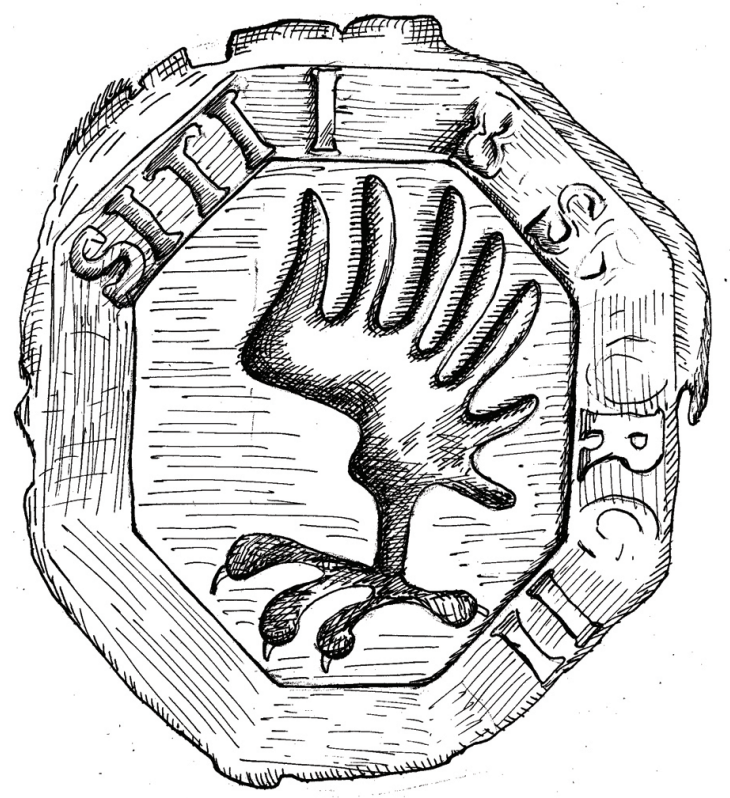

Obr. 7 Rekonštrukcia pečate prepošta Juraja z Čorne z r. 1402 (podla: MNL OL DL 1402; rekonštrukcia: M. Glejteková).

Fig. 7 Reconstruction of the seal of provost George of Csorna from 1402 (after MNL OL DL 1402; drawing: M. Glejteková).

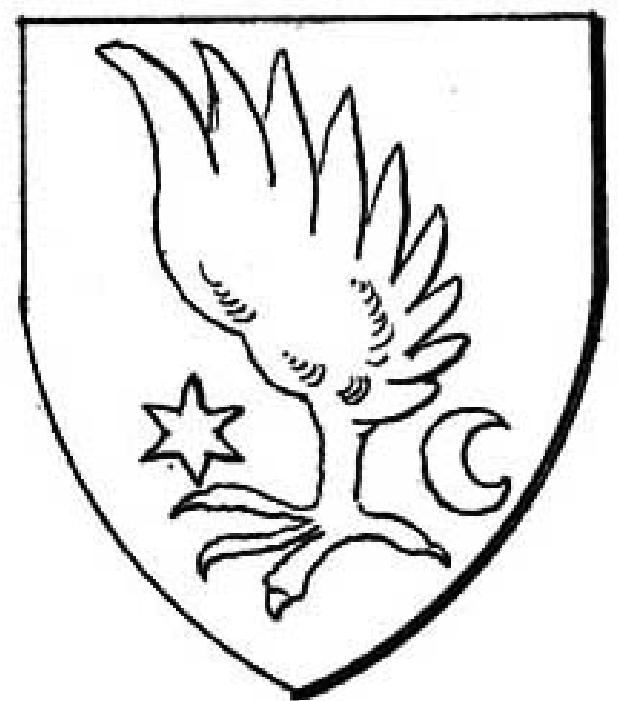

Obr. 8 Rekonštrukcia jedného z variantov erbového štítu Kanižaiovcov (zdroj: Siebmacher Csergheö 1885 - 1892).

Fig. 8 Reconstruction of a variant of a coat of arms shield of the Kanižai family (source: Siebmacher - Csergheö 1885 - 1892). 


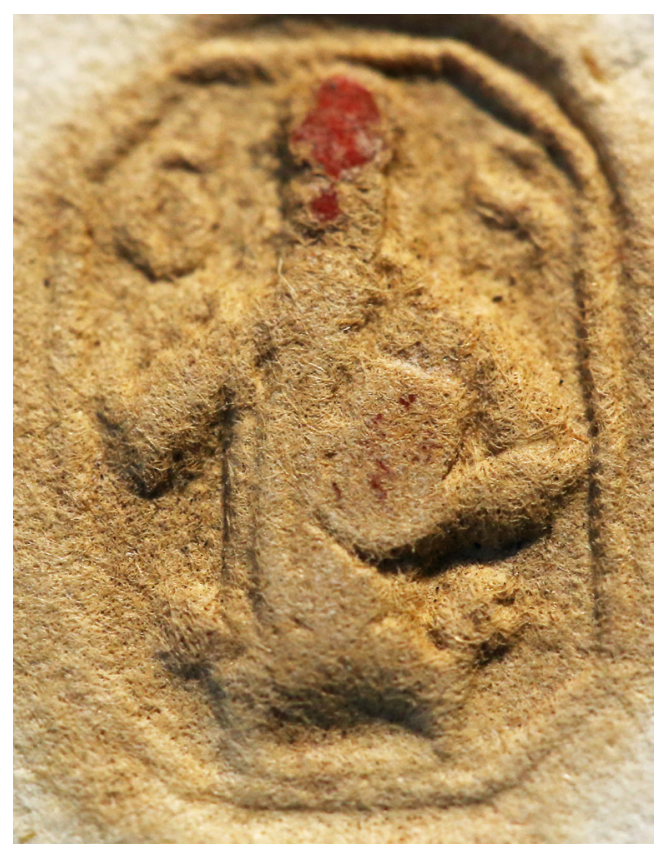

Obr. 9 Pečat' ostrihomského arcibiskupa Juraja z Pavloviec z r. 1437 (zdroj: AMB, f. MMB, Sign. 1490; foto: AMB).

Fig. 9 The seal of the Esztergom archbishop George of Pavlovce from 1437 (source: AMB, f. MMB, Sign. 1490; photo: AMB).

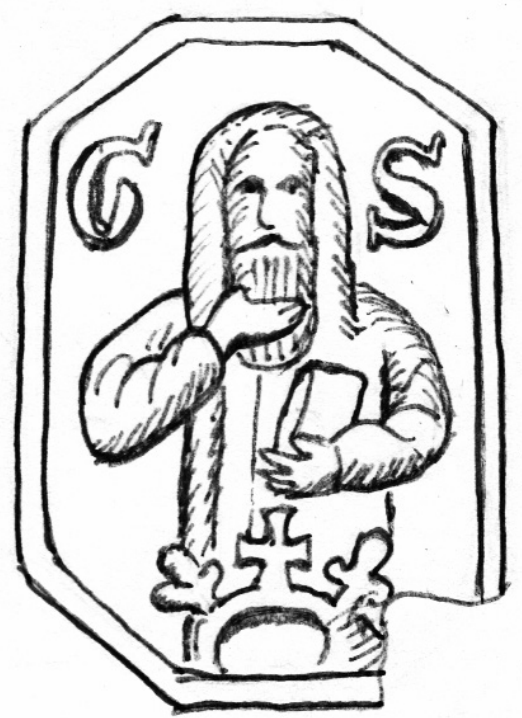

Obr. 10 Rekonštrukcia pečate ostrihomského arcibiskupa Juraja z Pavloviec (podla: Hegedüs 2000, 119, Nr. 90; rekonštrukcia: M. Glejteková).

Fig. 10 Reconstruction of the seal of the Esztergom archbishop George of Pavlovce (after Hegedüs 2000, 119, Nr. 90; drawing: M. Glejteková). 


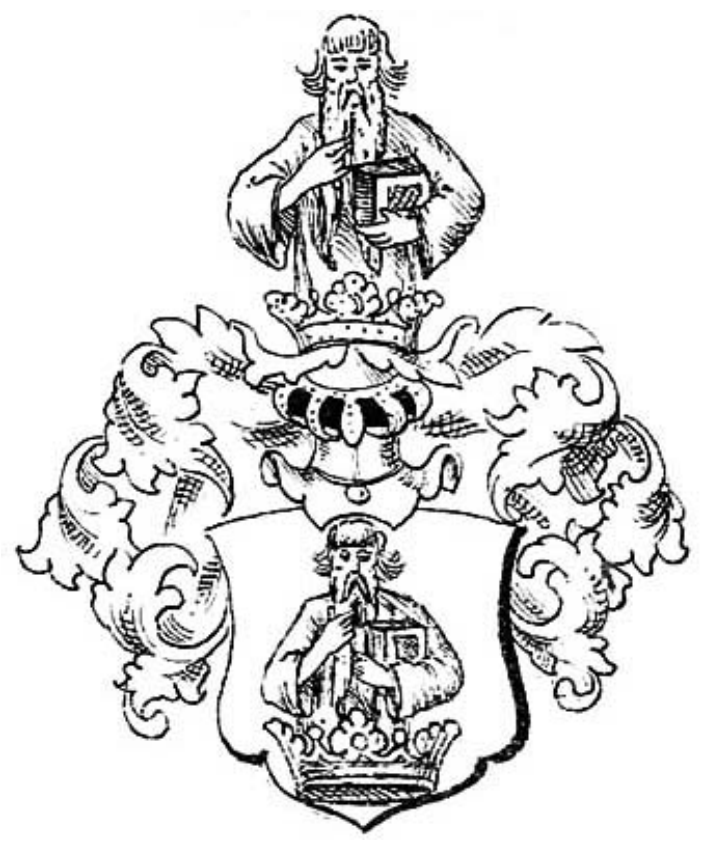

Obr. 11 Rekonštrukcia rodového erbu pánovz Pavloviec (zdroj:Siebmacher-Csergheö1885-1892).

Fig. 11 Reconstruction of the family coat of arms of the Pavlovce nobles (source: Siebmacher Csergheö 1885 - 1892).

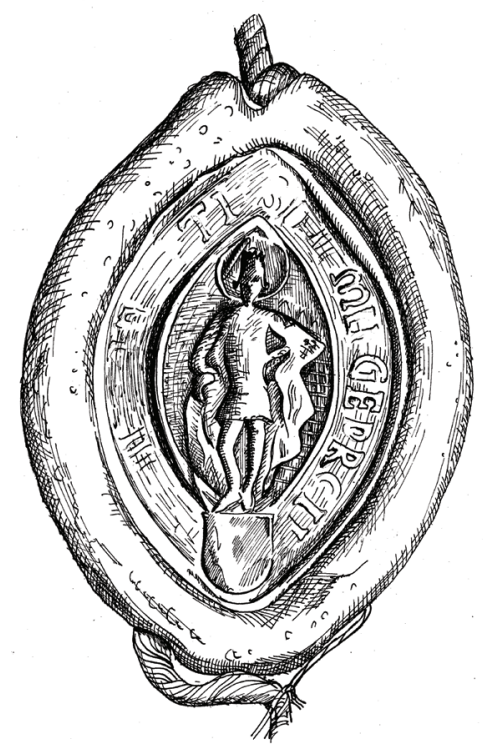

Obr. 12 Rekonštrukcia pečate prepošta Juraja z Kežmarku z r. 1421 (podla: MNL OL DL 74887; rekonštrukcia: M. Glejteková).

Fig. 12 Reconstruction of the seal of provost George of Kežmarok from 1421 (after MNL OL DL 74887; drawing: M. Glejteková). 


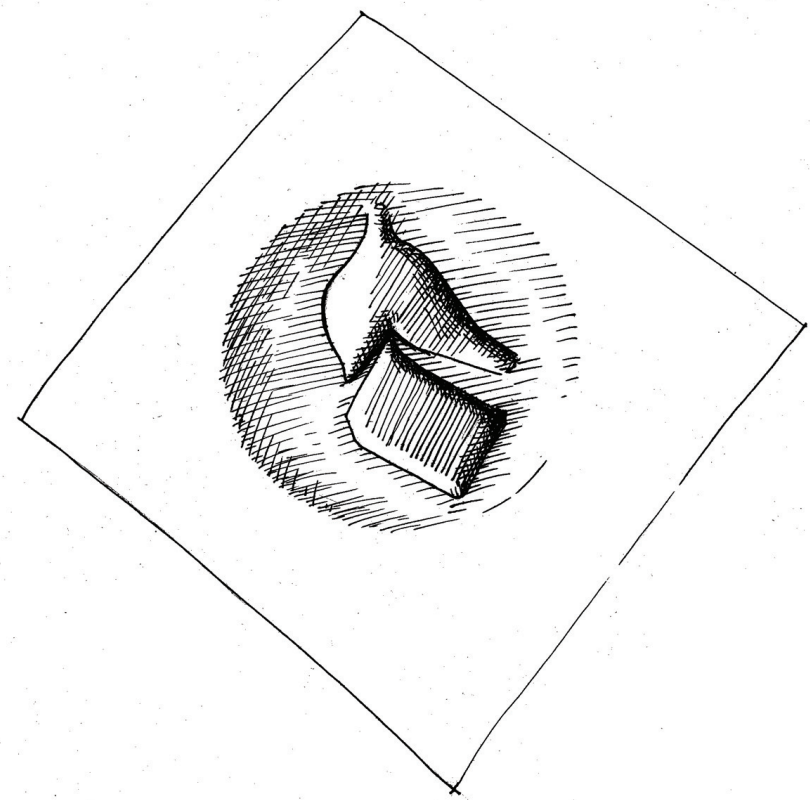

Obr. 13 Rekonštrukcia menšej pečate prepošta Juraja z Kežmarku z r. 1432 (podla: MNL OL DL 12448; rekonštrukcia: M. Glejteková).

Fig. 13 Reconstruction of a smaller seal of provost George of Kežmarok from 1432 (after MNL OL DL 12448; drawing: M. Glejteková).

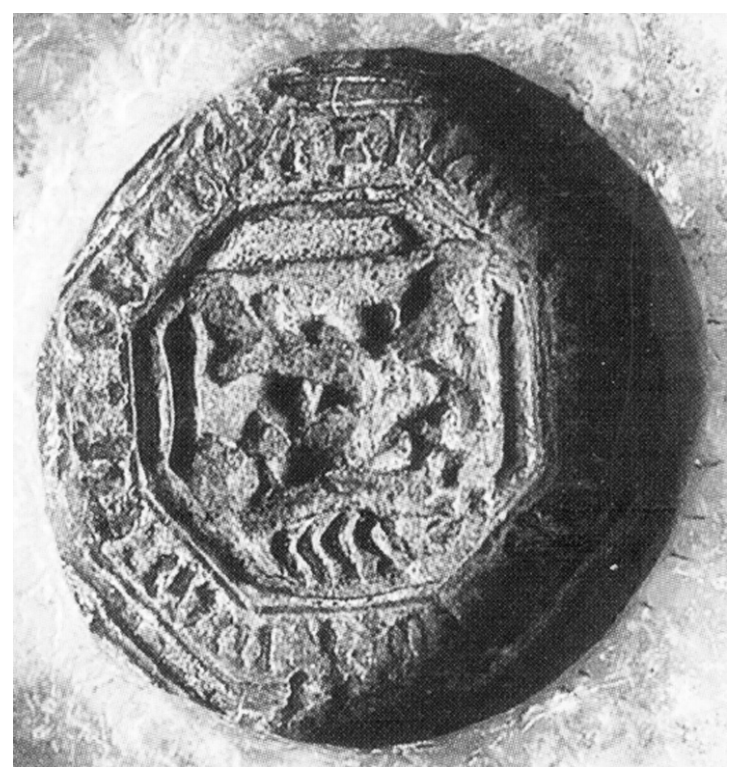

Obr. 14 Pečat’ spišského prepošta Jána Stocka z r. 1449 (zdroj: Vrtel 2003, 127).

Fig. 14 The seal of provost John Stock from 1449 (source: Vrtel 2003, 127). 


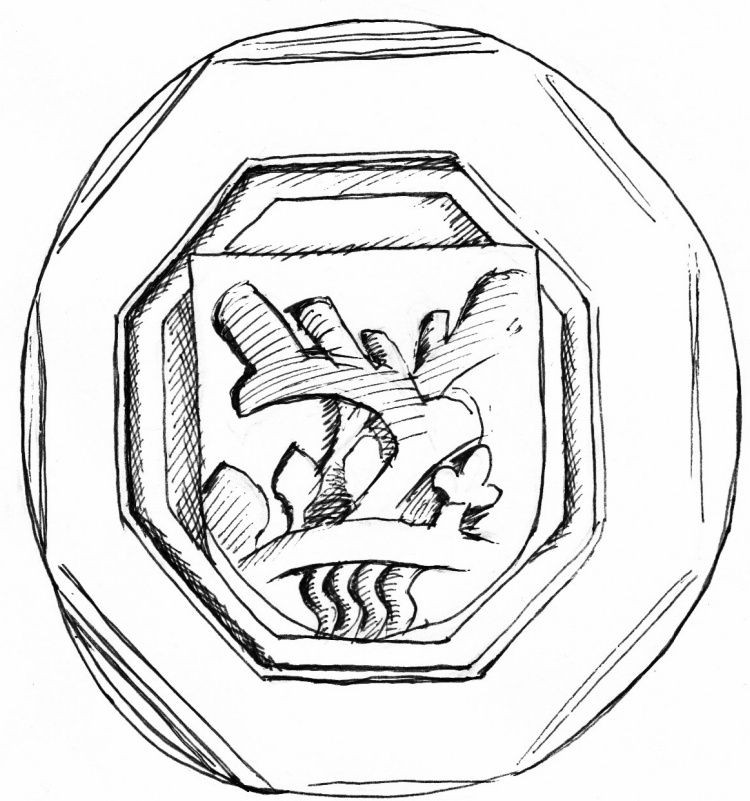

Obr. 15 Rekonštrukcia erbu na pečati Jána Stocka z r. 1449 (podla: Vrtel 2003, 127; rekonštrukcia: M. Glejteková).

Fig. 15 Reconstruction of the coat of arms on the seal of John Stock from 1449 (after Vrtel 2003, 127; drawing: M. Glejteková).

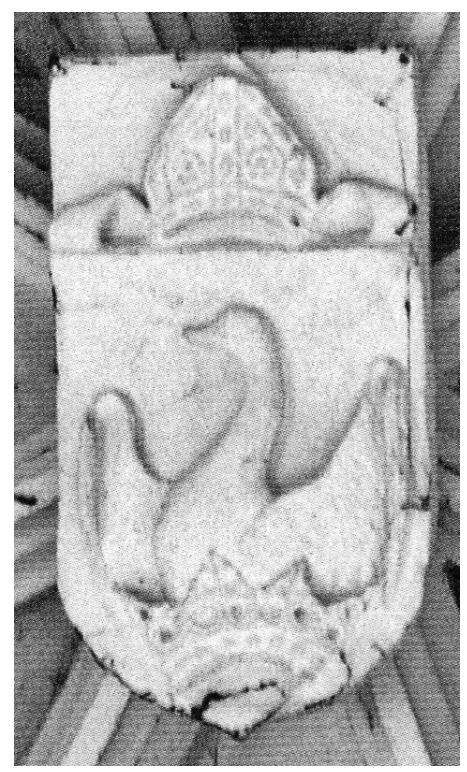

Obr. 16 Erb prepošta Gašpara Backa na klenbovom svorníku chrámu v Spišskej Kapitule z r. 1491 (zdroj: Janovská - Olejník 2017, 211).

Fig. 16 The coat of arms of provost Caspar Back on the roof boss in the Spiš Chapter Church from 1491 (source: Janovská - Olejník 2017, 211). 


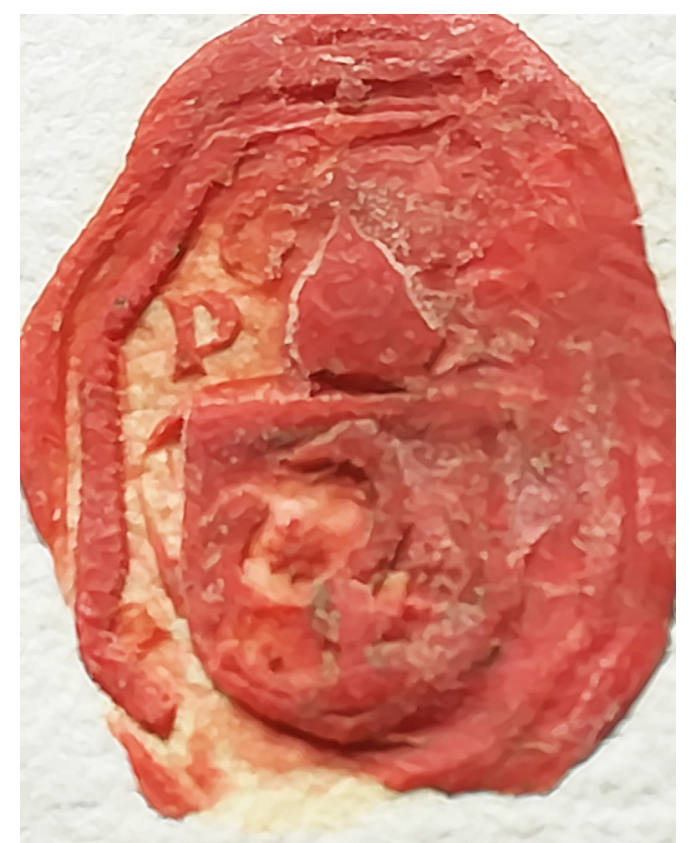

Obr. 17 Pečat prepošta Gašpara Backa z r. 1488 (zdroj: ŠA Pr-AP, f. MMK, Sign. U949/21; foto: P. Labanc).

Fig. 17 The seal of provost Caspar Back from 1488 (source: ŠA Pr-AP, f. MMK, Sign. U949/21; photo: P. Labanc).

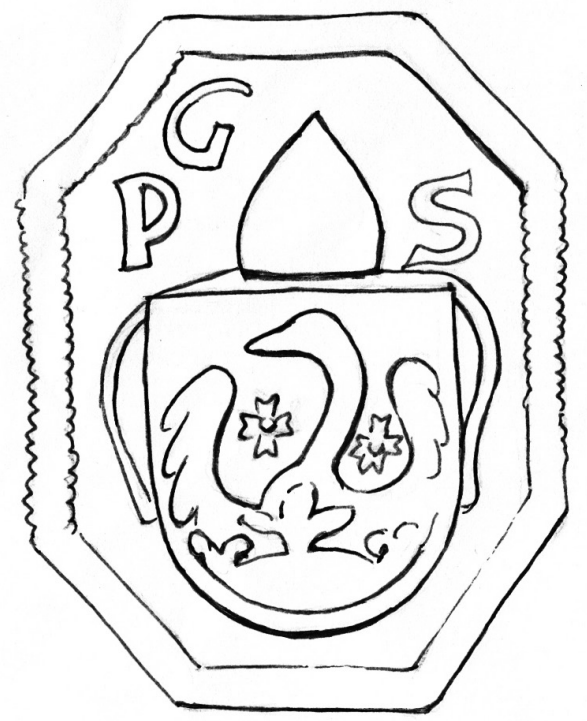

Obr. 18 Rekonštrukcia erbu na pečati Gašpara Backa z r. 1488 (podla: ŠA Pr-AP, f. MMK, Sign. U949/21; rekonštrukcia: M. Glejteková).

Fig. 18 Reconstruction of the coat of arms on the seal of provost Caspar Back from 1488 (after ŠA Pr-AP, f. MMK, Sign. U949/21; drawing: M. Glejteková). 


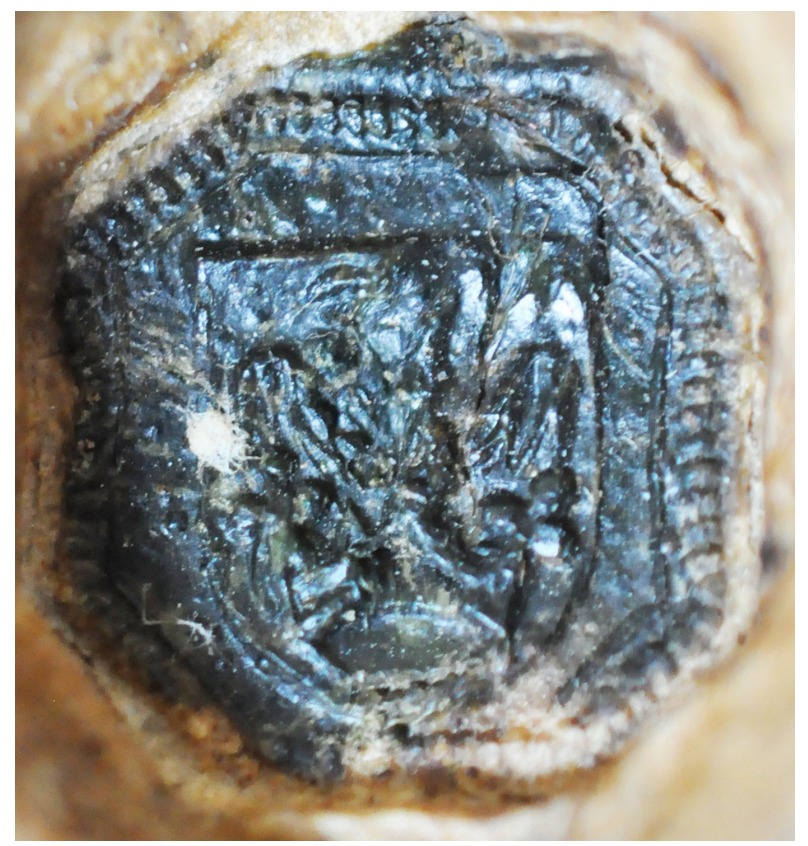

Obr. 19 Pečat prepošta Gašpara Backa z r. 1474 (zdroj: AGAD, f. ZDP, Sign. 5583; foto: M. Hlebionek).

Fig. 19 The seal of provost Caspar Back from 1474 (source: AGAD, f. ZDP, Sign. 5583; photo: M. Hlebionek).

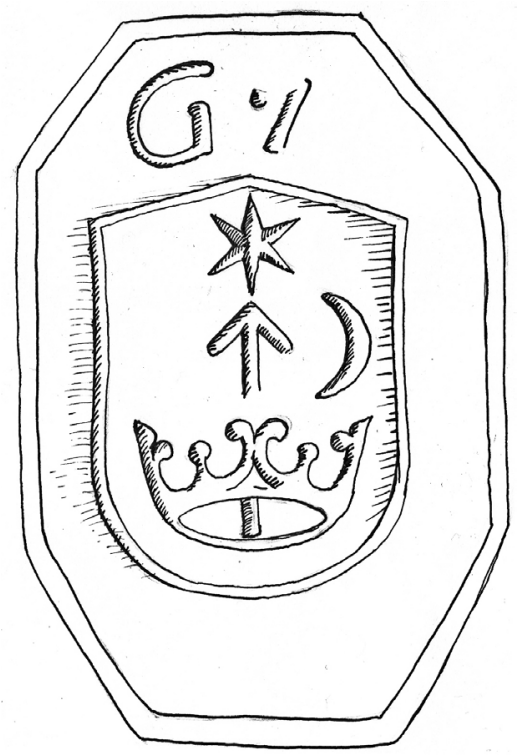

Obr. 20 Rekonštrukcia erbu na pečati prepošta Juraja z Mecske z r. 1498 (podla: MNL OL DL 59875, rekonštrukcia: M. Glejteková).

Fig. 20 Reconstruction of the coat of arms on the seal of provost George of Mekcse from 1498 (after MNL OL DL 59875, drawing: M. Glejteková). 


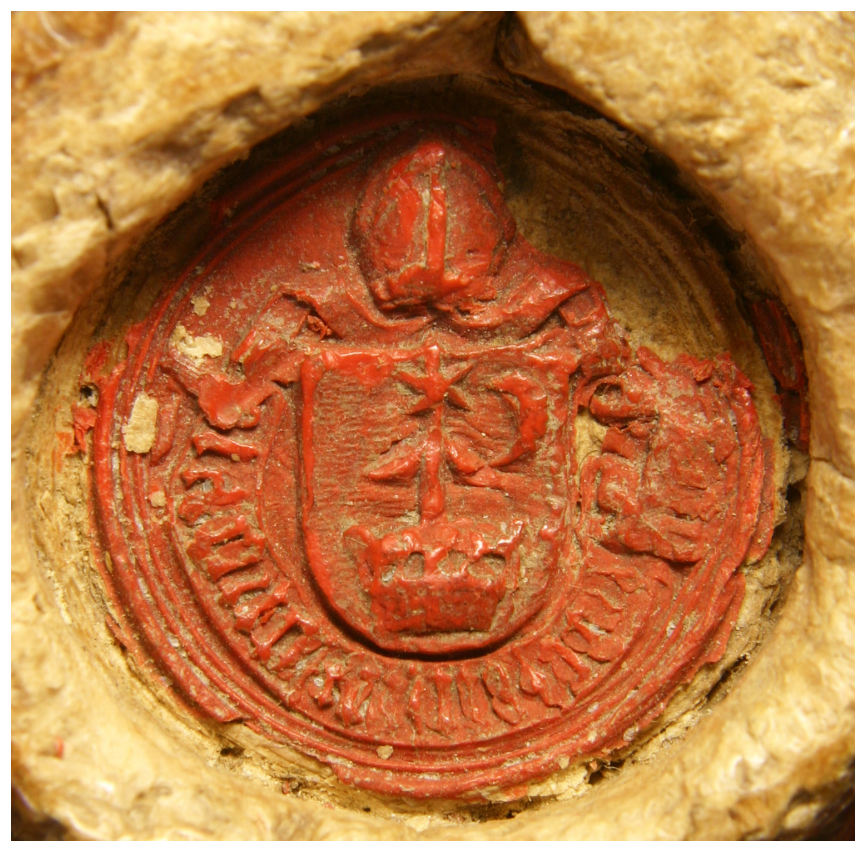

Obr. 21 Pečat titulárneho oropského biskupa Jána z Mecske z r. 1503 (zdroj: SA Le, f. SaSk, Nr. 5; foto: V. Olejník).

Fig. 21 The seal of the titular Oropa bishop John of Mekcse from 1503 (source: SA Le, f. SaSk, Nr. 5; photo: V. Olejník).

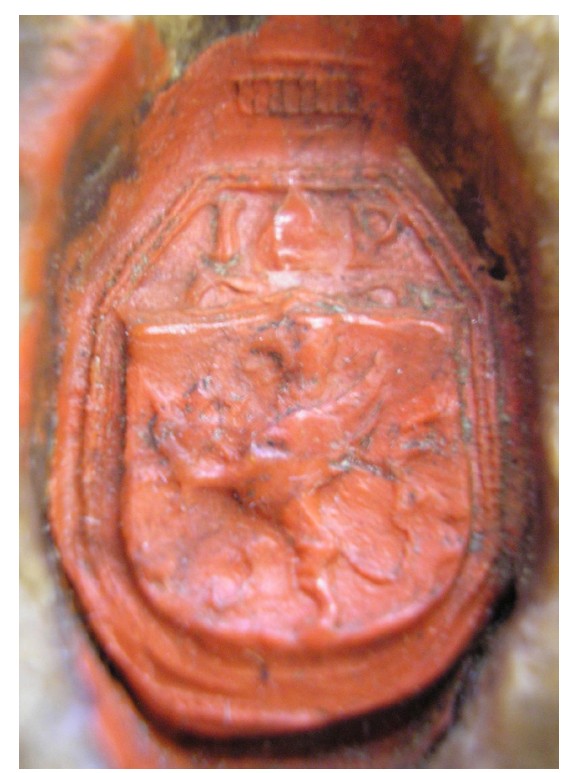

Obr. 22 Pečat' Jána Horvátha s I. typom erbu z r. 1534 (zdroj: SA Le, f. SpP, Cap. 16, Fasc. 1).

Fig. 22 The seal of John Horváth with the type I coat of arms from 1534 (source: SA Le, f. SpP, Cap. 16, Fasc. 1). 


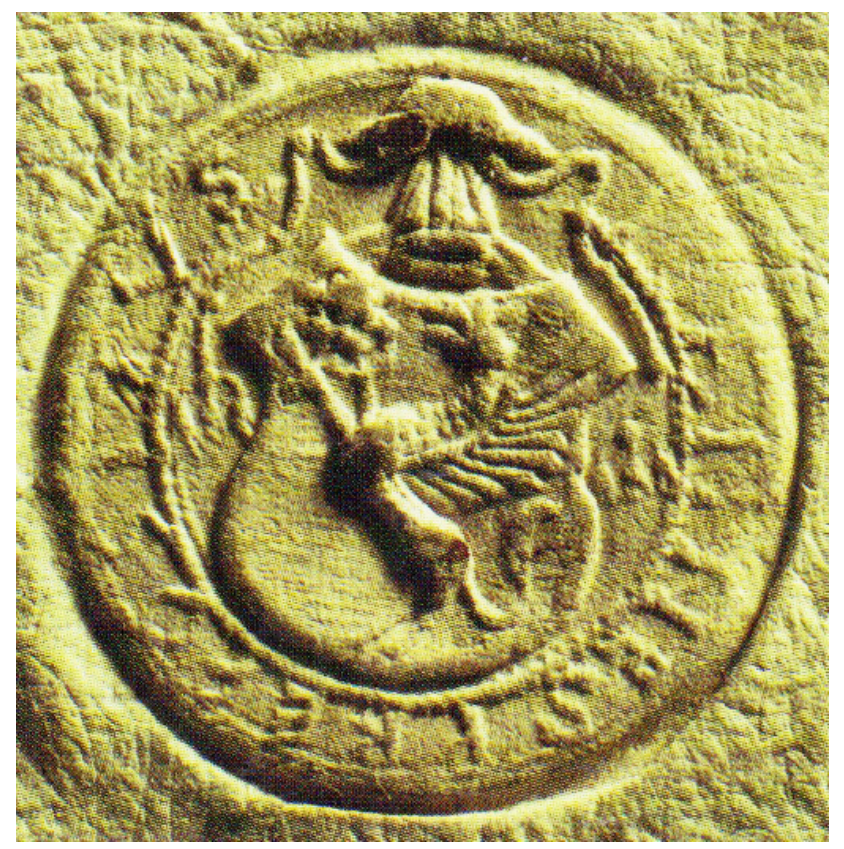

Obr. 23 Pečat Jána Horvátha s II. typom erbu z r. 1537 (zdroj: Vrtel 2003, 156).

Fig. 23 The seal of John Horváth with the type II coat of arms from 1537 (source: Vrtel 2003, 156).

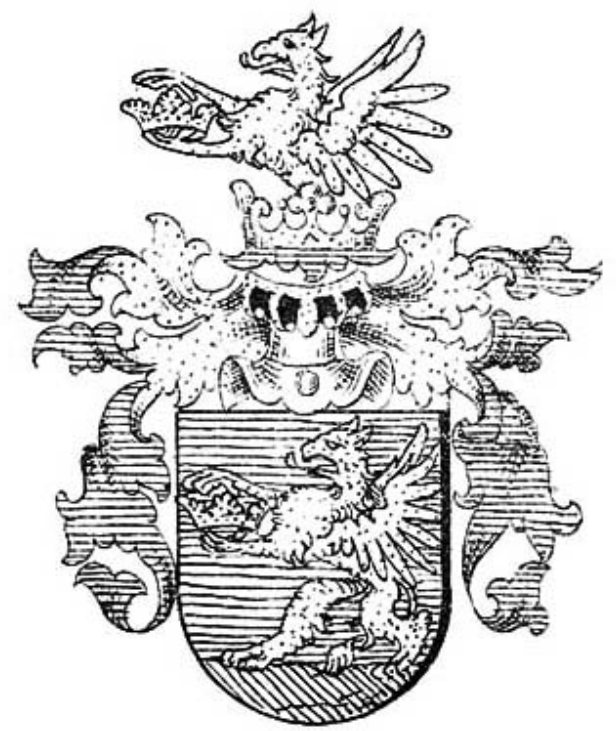

Obr. 24 Rekonštrukcia rodového erbu Jána Horvátha (zdroj: Siebmacher - Csergheö 1885 - 1892).

Fig. 24 Reconstruction of a family coat of arms of John Horváth (source: Siebmacher - Csergheö 1885 - 1892). 